\begin{abstract}
Iranica
Abstracta Iranica Revue bibliographique pour le domaine irano-aryen

Volume 34-35-36 | 2017

Comptes rendus des publications de 2011-2013
\end{abstract}

\title{
Barbara Kaim. Most Ancient Fire Temples : Wishful Thinking Versus Reality
}

\section{Rémy Boucharlat}

\section{(2) OpenEdition}

1 Journals

\section{Édition électronique}

URL : http://journals.openedition.org/abstractairanica/41812

DOI : 10.4000/abstractairanica.41812

ISSN : 1961-960X

Éditeur :

CNRS (UMR 7528 Mondes iraniens et indiens), Éditions de l'IFRI

\section{Référence électronique}

Rémy Boucharlat, «Barbara Kaim. Most Ancient Fire Temples : Wishful Thinking Versus Reality», Abstracta Iranica [En ligne], Volume 34-35-36 | 2017, document 22, mis en ligne le 30 décembre 2016, consulté le 01 octobre 2020. URL : http://journals.openedition.org/abstractairanica/41812 ; DOI : https://doi.org/10.4000/abstractairanica.41812

Ce document a été généré automatiquement le 1 octobre 2020.

Tous droits réservés 


\title{
Barbara Kaim. Most Ancient Fire Temples : Wishful Thinking Versus Reality
}

\author{
Rémy Boucharlat
}

\section{RÉFÉRENCE}

Barbara Kaim. « Most Ancient Fire Temples : Wishful Thinking Versus Reality », in : H. Fahimi and K. Alizadeh, eds., Nāmvarnāmeh, Papers in Honour of Massoud Azarnoush.

Tehran, Iran Negar, 2012, p. 131-138.

1 L'A. passe en revue les principaux « temples du feu » iraniens depuis Nush-i Jan, préachéménide, temple zoroastrien ou non, jusqu'aux monuments sassanides. Il faut exclure les lieux de culte en plein air, comme le mentionne Hérodote pour les Perses, puis Strabon au tournant de l'ère commune, pour l'Asie Mineure, car ce ne sont pas des temples construits. Le temple du feu prend sa forme peu à peu, celle d'un monument avec un espace principal centré, couvert d'une coupole, comme l'indique Mele Hairam au Turkménistan à la frontière iranienne, daté du II ${ }^{\mathrm{e}} \mathrm{s}$. de n.è., fouillé par l'A. Puis, plus systématiquement la coupole est portée par quatre arcs reposant sur des piliers. Les récentes découvertes en différentes régions d'Iran confirment que cette structure est bien caractéristique de la partie principale du temple du feu sassanide. 


\section{AUTEURS}

RÉMY BOUCHARLAT

CNRS, Lyon 